\title{
SENAI CIMATEC CONTRIBUTIONS FOR THE STRENGTHENING OF BRAZILIAN COMPANIES USING LEAN MANUFACTURING IN THE COMBAT TO COVID-19
}

Carlos César Ribeiro Santos', Ricardo de Oliveira Monteiro Russel.1, Leonardo Sanches de Carvalho', Victor Nunes Fontenelel', Nelson Ribeiro Carreira'

${ }^{1}$ Centro Universitário Senai Cimatec, Brasil

\begin{abstract}
SENAI CIMATEC, a technology center located in Bahia, has been in the spotlight in Brazil for the development of programs and projects to help companies and employees, in the midst of the pandemic of the Coronavirus SARS-CoV-2 disease. The purpose of this work is to present the project "Lean Manufacturing in support of the COVID-19 crisis", devloped by SENAI CIMATEC, in support of the Brazilian enterprises The methodology used was a case study and the results achieved thrive to the success of the program and demonstrate how the use of the Lean Manufacturing tools, in a remote access environment, can assist companies in conducting business consultancies.
\end{abstract}

Keywords: Lean Manufacturing. Industry. COVID-19.

\section{CONTRIBUIÇÕES DO SENAI CIMATEC PARA O FORTALECIMENTO DAS EMPRESAS BRASILEIRAS UTILIZANDO O LEAN MANUFACTURING NO COMBATE À COVID-19}

Resumo: O SENAI CIMATEC, centro de tecnologia localizado na Bahia, vêm se destacando no Brasil, entre outras ações sempre ligadas à tecnologia, pelo desenvolvimento de programas e projetos em auxílio às empresas e colaboradores, em meio à pandemia da doença Corona vírus SARS-CoV-2. Este trabalho tem como objetivo descrever o programa "Lean Manufacturing no Enfrentamento da Crise gerada pelo COVID-19", criado pelo SENAI CIMATEC, em apoio a indústria do Brasil. Foi utilizada uma metodologia própria do CIMATEC lastreada por um estudo de caso e os resultados alcançados apontam para o sucesso do programa e demonstram como a utilização de ferramentas Lean, utilizadas remotamente, podem auxiliar as empresas na realização de consultorias empresariais remotas.

Palavras-chave: Lean Manufacturing. Indústria. COVID-19.

\section{INTRODUCTION}


The 2019 outbreak of coronavirus disease (COVID-19) had a huge impact on industries around the world. It was no different in Brazil. In a research released by the Business Consultation [1], published by the National Industry Confederation (CNI), points out that some of the main problems due to the pandemic are: the drop in products demand, the difficulty in obtaining consumable goods and raw materials, and the reduction of supply of working capital in the national financial system. CNI also points out that $92 \%$ of the consulted industries are having negative impacts. Of this total, $40 \%$ correspond to companies which had a heavy impact, $27 \%$ to companies which had a medium impact and $25 \%$ to companies that had a small impact. In four out of ten industries consulted, about $41 \%$, the main production was ceased due to the crisis. The situation is declared as serious and actions must be taken in order to help the Brazilian industry to recover.

From this perspective, recent world history has demonstrated the importance of Lean philosophy to come for the aid of companies and, mainly, for their recovery in times of crisis. At the end of World War II, Japanese industry had a very low productivity and an enormous lack of resources. Thus, when returning from a trip to the United States, in which he observed that supermarkets replaced the goods on the shelves from the moment they were sold, Toyota engineer Taiichi Ohno led the development of the Toyota Productive System (TPS), which was designed to increase the efficiency and effectiveness of companies, avoiding waste and the main industrial problems. Hence, the pillars of what would later be called Lean Manufacturing were born, a management philosophy developed by Toyota, which called the attention of other companies in the world only with the arrival of another crisis, the 1973 energy crisis. In this period, the Toyota proved to be an efficient company with its relentless pursuit of waste riddance and consequent increase in productivity [2].

Therefore, in the face of the scenario of recession and uncertainty, caused by the pandemic Sars-COVID-19, in Brazil, it became essential to support research and technology centers to help Brazilian companies in order to mitigate the impacts on industrial productivity. In this regard, SENAI CIMATEC, whose mission is to support the Bahian and Brazilian industry, decided to present a proposal for a technological solution capable of helping the business community to face this crisis,

Considering the moment of uncertainty, the importance of Lean Manufacturing and the presence of SENAI CIMATEC in this scenario, this scientific article presents the following driving question: How to adapt the Lean Manufacturing tools, in face of the COVID-19 pandemic, to help with the companies' productivity?

The general objective of this article will be to present the practical results of the program carried out by SENAI CIMATEC, to support 40 (forty) companies in the battle against the pandemic, using the Lean Manufacturing methodology as a technological basis. The specific objectives of this article are:

a) Define the primary lean tools used by the program;

b) Explain the performance indicator "COVID Radar";

c) Present a detailed analysis on the program created by SENAI CIMATEC to support industries through the use of Lean Manufacturing.

Section two of this article presents the methodology that was used to build this research, as well as the case study and its technical characteristics. In session three, we present the results of the program, which is the subject of investigation in this article and, in the last session, the conclusions and technical impressions on the topic. 


\section{METHODOLOGY}

Scientific research can be defined as the search for information elaborated in a systematic, orderly and rational way, which obeys academic norms, aiming to solve a proposed problem, and contribute to the extension of scientific knowledge. According to [3], the investigation must be followed by a research project that aims to link the empirical data to the initial questions of the study in a logical way, which will allow ultimately to reach its conclusions.

This scientific article is labeled as a case study because, according to [4], it consists in a deep study of an object in a way that allows its detailed knowledge. Hence, this research produces a case study about the "Lean Manufacturing in support of the COVID-19 crisis", a program developed by SENAI CIMATEC, in support of partner companies. The program aims to support entrepreneurs in the face of this scenario of recession and uncertainty, due to the COVID-19 pandemic, by raising awareness and guiding actions aimed at mitigating impacts on industrial productivity, using the principles of the Lean Manufacturing. To carry out this program, the following methodological steps were defined:

(1) Definition of which and how many companies would apply to the program. Twenty approved companies were chosen in the Northeast region and twenty in the Southeast region of the country;

(2) Definition of the main lean tools used by the program. The tools chosen were Value Stream Mapping (VSM), Added Value Analysis, Cell Design, Standard Operating Procedure (SOP), Line Balancing and the Spaghetti Diagram;

(3) Development of four technical live streaming programs broadcasted directly from Brazil Model Factory (a test-bed 4.0 laboratory that includes lean technology located at SENAI CIMATEC) (figure 01), through CIMATEC's YouTube channel, addressing the following topics: measures to prevent COVID-19 in the industry, common ground between the risks of the pandemic and the waste of production and the use of the Lean Manufacturing tools in the battle against COVID-19.

Figure 1. Brazil Model Factory

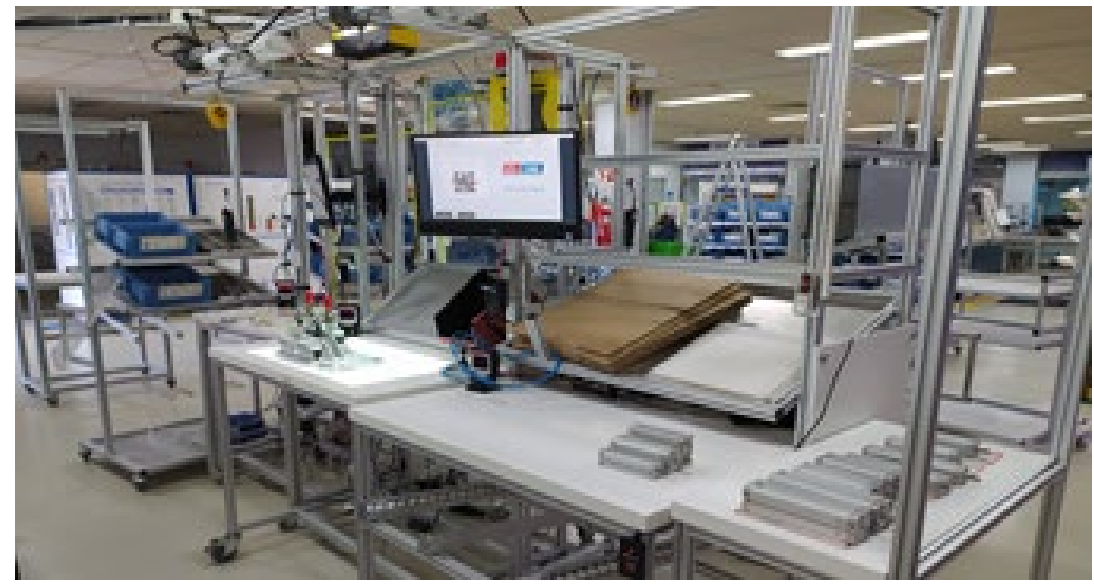


(4) Technical and statistical analysis on the results of the live streaming programs such as: simultaneous viewers, total views, comments and impressions;

(5) Remote guidance provided by the institutions' lean consultants. Such guidelines aim to guide companies as they apply lean tools, develop an operational tactical action plan and evaluate the results achieved by the 40 companies in the program in the light of productivity, inventory / WIP (work in process), defects and setup time.

\subsection{Lean Tools}

Lean Manufacturing is a management philosophy focused on reducing the eight types of waste: transport, inventory, motion, waiting, overproduction, over-processing, defects and skills. This philosophy has tools capable of helping companies to achieve high productivity gains and waste reduction. In the program "Lean Manufacturing in support of the COVID-19 crisis", the object of this research, some lean tools were chosen for their ability to help companies to preserve and even increase their productivity levels even in the face of the crisis.

The first tool was the VSM (Value Stream Map). According to [5], a value flow is every action, (adding value or not) necessary to bring a product through all the essential product flows. Usually the VSM is used to understand the product flow in a company, from the supply of raw materials to the final consumer, analyzing bottlenecks, cycle times, work-in-process, number of operators and the information flow. The second tool used by the program was added value analysis. According to [6], added value activities are generally all those that have some value when viewed from the client's perspective.

According to [7], line balancing, the third tool used in this research, is a term that refers to the process of equalizing the distribution of activities among operators of a production line in order to optimize available resources. One of its best known and applied approaches is from Lean Manufacturing and is called Yamazumi. Focused on balancing resources, this Lean tool is based on two of the basic elements of Lean: continuous flow and high added value [8]. The fourth and final tool, the Spaghetti Diagram, is used to visualize transport and motion. When transport routes are designed, it is easier to find opportunities and reduce waste. The Spaghetti Diagram is usually drawn by hand, over an image of the company's layout [9]. Finally, standardized work allows the definition of procedures that will ensure that the work is done correctly, thus ensuring the quality of the processes. The following session will present the practical results achieved by the companies participating in the program through the remote meetings carried out by the project team.

\section{RESULTS AND DISCUSSION}

This article has presented in its introductory session the following guiding question: How to adapt the lean manufacturing tools to help the companies, in face of the COVID-19 pandemic? From the conception tools presented in the previous session, to carry out this adaptation, technical protocols were defined and presented 
in the live streaming. These protocols were also the subject of remote meetings carried out by the consultants' team to the participating companies:

a) Technical Protocol 1 (Added Value Analysis): As the main focus of eliminating waste in the manufacturing environment, it is common to redesign industrial layouts, bringing workstations and operators closer together in order to reduce travel and increase productivity. However, in face of the pandemic context, this traditional approach must be revaluated and the minimum distance of employees between 1.5 and 2 meters must be taken into consideration, in addition to the implementation of physical or flow barriers aimed at reducing possible contagion points. As a practical example, for Brazil Model Factory, the distances between workstations were maintained and the pathway of each operator were drawn on the floor.

b) Technical Protocol 2 (COVID-19 Radar): Aiming at the continuous monitoring of some key indicators for production during the pandemic, the COVID-19 Radar (figure 2) was created. It uses the measurement and presentation structure of the $5 S$ Radar, a commonly known indicator of the Lean, to monitor the current position of a company or a specific sector in the face of the pandemic. The indicator consists of four categories: 1) the environment hygiene and safety; 2) the employee hygiene and health; 3) the dissemination of information; 4) managing the flow of entry and exit of people. The grades for each category vary from 1 to 2 and are obtained from a questionnaire that must be done periodically. In order to produce a standardized assessment, the following indicators were used: grade 0 must be understood as "not done"; grade 1 as "partially accomplished"; and grade 2 as "accomplished". Ideally, the average grades of the categories analyzed should be close to grade 2 . This means that the company is complying with the recommendations to face the COVID-19 disease.

Figure 2. COVID Radar

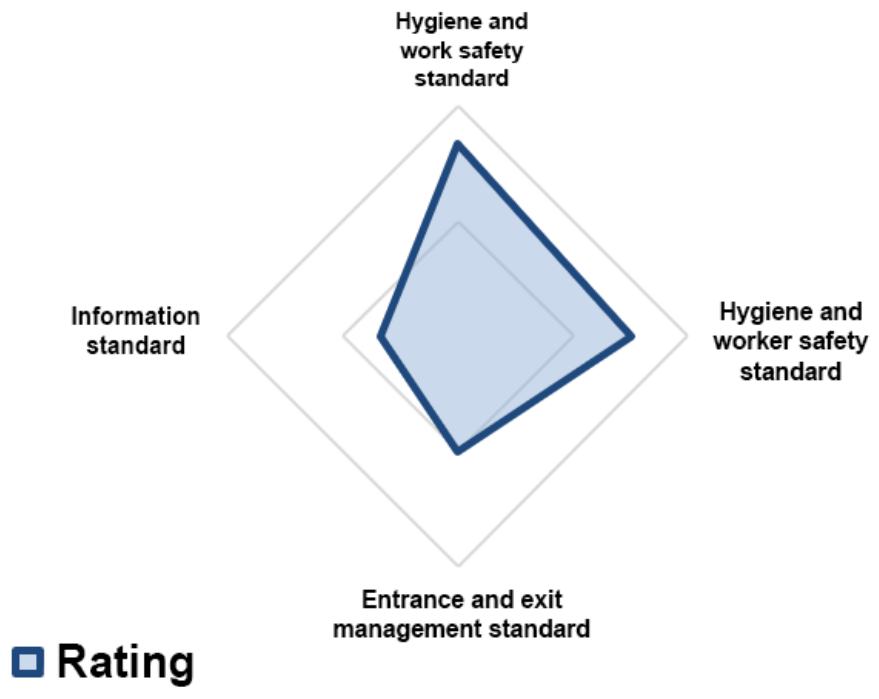


For the proper monitoring of this and other indicators used by companies, Lean good practices advocate holding meetings and performance dialogues at the beginning and end of shifts. However, due to the pandemic, it is important to rethink such practices and avoid unnecessary crowd environments. For the Brazil Model Factory's performance dialogue and KPI's monitoring practices, the number of participants was reduced, pre-determined and the position of each person was signed on the floor, in addition to the incorporation of the COVID-19 Radar as a safety indicator.

c) Technical Protocol 3 (Line Balancing and Cell Design): During the pandemic period, the materialization of this concept goes beyond the already traditional productive improvements. The continuous flow application ensures that the production items pass once per workstation and, when combined with the correct operators and the workstations hygiene, reduces the possible contagion points within the production environment. As an example, for Brazil Model Factory, hygiene steps were added to the cylinders before shipping to the customer, ensuring their safety and satisfaction.

d) Technical Protocol 4 (VSM): Based on this definition, the VSM shows itself as a tool of great help for companies to adapt to a pandemic such as COVID19. When carrying out an analysis of the product flow, it is possible to pinpoint all the sectors through which it travels, allowing to trace possible points of contagion among operators. Its use is also evidenced when the information flow is analyzed. At this time, the company must focus on digital information within production, at the expense of physical information, such as printed production orders. If it is not possible to replace physical information with digital information, focus on reducing the number of people who have access to these physical production orders, avoiding the contact of this object by several operators.

e) Technical Protocol 5 (Spaghetti Diagram): Although the main focus of the Spaghetti Diagram is to verify waste in motion and transport, in the current pandemic scenario it can also be used to check possible contagion points and create independent paths for employees and customers. At Brazil Model Factory, after designing and analyzing the diagram, unique path routes were established for each operator, marked on the floor, in order to avoid backflow and contact with other employees.

The practical results of the program were reflected on the companies. Initially, it is worth highlighting the success of the live streaming held with the large participation of employees from the 40 selected companies. The indicators point out to the number of 1,135 simultaneous viewers, 4,025 views, 1,508 general comments and 32,000 impressions. The survey carried out with the participants still shows that $89.65 \%$ of the participants said they had their expectations met or exceeded, $86.2 \%$ said they were satisfied or very satisfied and $89.65 \%$ stated that the content presented during the lives had relevance for their jobs.

Regarding the practical results of the program for the selected companies, these are the result of the remote meetings. These meetings occurred as follows: (i) A total of eleven consultants involved in the project; (ii) Remote assistance to the forty selected companies in the program (20 companies in the Northeast region and 20 companies in the Southeast region); (iii) 220 activities were developed in the action plans for application in companies during and after the end of the guidelines and; (iv) 
160 hours were invested in remote meetings, with 1 hour per week for each company. The results of the remote meetings were quite positive, as we can see in table 01 below:

Table 1. Remote Meetings Results

\begin{tabular}{l|c|}
\multicolumn{1}{c|}{ Indicators } & Results \\
\hline Productivity Increase & $35 \%$ \\
Defects Reduction & $75 \%$ \\
Inventory Reduction & $20 \%$ \\
Setup time Reduction & $30 \%$ \\
\hline
\end{tabular}

Among the results obtained by the online meetings, it was possible to observe very expressive gains, even in a short amount of time. First, there was a $35 \%$ increase in productivity in a packaging company after a reduction in transportation, handling and incidental activities. $75 \%$ reduction of defects in a company in the food sector, due to adjustments of an underused machine in production processes. $20 \%$ reduction in inventories of a furniture company, after applying the $5 \mathrm{~S}$ principles. Finally, the program also enabled a $30 \%$ reduction in setup time in a company in the print sector, after changes in layout and standardization. It is worth noting that the pilot action lasted for only 1 month, and the results obtained were collected during just one month of action. It is expected to obtain further gains in long term, which may be presented in future studies

\section{CONCLUSION}

The program "Lean Manufacturing in support of the COVID-19 crisis", developed by SENAI CIMATEC, presented expressive results in its first pilot.

Initially, it is worth highlighting the success and scope of all the live streaming broadcasts, with a significant number of participants. The program also corroborated the importance of adapting and making a productive environment safer for industrial operators in the face of the current pandemic. In addition, the program was able to adapt lean tools to a remote learning methodology, and showed its potential through the expressive indicators of results achieved by the involved companies. Finally, the Lean Manufacturing philosophy ensure once again how it can be crucial in a moment of crisis.

\section{REFERENCES}

1 Consulta Empresarial. Publicação da Confederação Nacional da Indústria - CNI. www.cni.com.br. Diretoria de Desenvolvimento Industrial - DDI. Gerência Executiva de Política Econômica - PEC.

${ }^{2}$ OHNO, Taiichi. O Sistema Toyota de Produção . Porto Alegre: Bookman, 1999.

${ }^{3}$ YIN, R. K. Estudo de Caso: planejamento e métodos. Porto Alegre: Bookman, 2005. 
${ }^{4}$ GIL, A. C. Como elaborar projetos de pesquisas. São Paulo: Atlas, 2002.

${ }^{5}$ SHOOK, John; ROTHER, Mike. Learning to See: Value Stream Mapping to Add Value and Eliminate MUDA: Lean Enterprise Institute, (1999).

${ }^{6}$ MONDEN, Y. Sistema Toyota de Produção: Uma abordagem integrada ao just-intime. Porto Alegre: Bookman, 2015.

7 KUMAR, N.; MAHTO, D. Assembly Line Balancing: A Review of Developments and Trends in Approach to Industrial Application, Global Journal of Researches in Engineering, Industrial Engineering, Vol. 3 Iss. 2, 2013

${ }^{8}$ WOMACK, J. P.; JONES, D. T. A mentalidade enxuta nas empresas. 5. ed. Rio de Janeiro: Campus, 1998.

9 WILSON, Lonnie. How to Implement Lean Manufacturing. McGraw Hill Professional. 2009. 